\title{
Marine natural compounds can be efficient toward aflatoxigenic Aspergillus flavus strain
}

\author{
Yasmim Dantas Crivelenti ${ }^{*}$, Cyntia AM Arevabini ${ }^{1}$, Mariana H De Abreu', Tamires Aparecida Bitencourt ${ }^{1}$, \\ Thaís B Mesquita', Bruna AM Cantelli ${ }^{1}$, Mario FC Santos ${ }^{2}$, Roberto GS Berlinck², Eduardo Hajdu', \\ Renê de O Beleboni ${ }^{1}$, Mozart Marins ${ }^{1}$, Ana Lúcia Fachin ${ }^{1}$ \\ From 5th Congress of the Brazilian Biotechnology Society (SBBIOTEC) \\ Florianópolis, Brazil. 10-14 November 2013
}

\section{Background}

The presence of high levels of aflatoxin is a serious problem to the production of raw peanuts and peanut crumbs. The high incidence of aflatoxin in peanuts in our country is mainly due to problems in primary production. High humidity and temperature conditions increase the likelihood of Aspergillus development and aflatoxins production, which is worsened during rainy weather [1]. Aflatoxins may remain in the food after the death of fungus without visible alterations [2]. The effects of aflatoxins on human and animal health, besides resistance of fungi to conventional antifungal agents has motived the search for new inhibitors. The research of marine natural products from sponges has been considered as a promising source for the development of new antifungal agents in order to discover compounds more effective and less toxic [3]. The objective of this study was to evaluate the antifungal activity of 21 marine natural compounds toward an aflatoxigenic A.flavus ATCC strains.

\section{Methods}

Aflatoxin producing (CCT 7836) and non producing (ATCC9643) A. flavus strains were purchased from Fundação André Tosello, Campinas, Brazil and were kept in Sabouraud media at $35^{\circ} \mathrm{C}$. The minimum inhibitory concentration (MIC) of 21 sponge marine natural products, identified as SM1 to SM21, toward the two strains of $A$. flavus was determined by microdilution assay in 96-well plates using RPMI medium according to the protocol NCCLS M-38 [4] for 7 days at 37C, using commercial antifungal cercobin as control.

'Unidade de Biotecnologia, Universidade de Ribeirão Preto, CEP 14096-900, Ribeirão Preto, SP, Brazil

Full list of author information is available at the end of the article

\section{Results and conclusions}

The marine product SM5 $(\mathrm{CIM}=3.9 \mu \mathrm{g} / \mathrm{mL})$ was more effective than cercobin $(\mathrm{CIM}=7.8 \mu \mathrm{g} / \mathrm{mL})$ against $A$. flavus control aflatoxin producer strain. Moreover, marine product SM5 $(\mathrm{MIC}=1.9 \mu \mathrm{g} / \mathrm{mL})$ was also a more effective antifungal agent than cercobin $(\mathrm{MIC}=3.9 \mu \mathrm{g} / \mathrm{mL}$ ) against the A. flavus ATCC strain. The findings suggest that natural marine products are a promising source of new molecules for the development of antifungal compounds against aflatoxigenic fungus that affect public health and the food production.

\section{Acknowledgements}

This study was supported by grants from Fundação de Amparo à Pesquisa do Estado de São Paulo, CNPq, CAPES and PET-MEC.

\section{Authors' details}

'Unidade de Biotecnologia, Universidade de Ribeirão Preto, CEP 14096-900, Ribeirão Preto, SP, Brazil. ${ }^{2}$ Instituto de Química de São Carlos, Universidade de São Paulo, CP 780, CEP 13560-970, São Carlos, SP, Brazil. ${ }^{3}$ Museu Nacional, Universidade Federal do Rio de Janeiro, Quinta da Boa Vista, s/n, Rio de Janeiro, RJ, Brazil.

\section{Published: 1 October 2014}

\section{References}

1. Hedayati MT, Pasqualotto AC, Warn PA, Bowyer P, Denning DW: Aspergillus flavus: human pathogen, allergen and mycotoxin producer. Microbiology 2007, 153:1677.

2. Yu J, Cleveland TE, Nierman WC, Bennett JW: Aspergillus flavus genomics: gateway to human and animal health, food safety, and crop resistance to diseases. Revista Iberoamerica de Micologia 2005, 22:194.

3. Mayer AM, Rodriguez AD, Berlinck RG, Fusetani N: Marine pharmacology in 2007-8: Marine compounds with antibacterial, anticoagulant, antifungal, anti-inflammatory, antimalarial, antiprotozoal, antituberculosis, and antiviral activities; affecting the immune and nervous system, and other miscellaneous mechanisms of action. Comparative biochemistry and physiology Toxicology \& pharmacology: CBP 2011, 153:191-222.

4. Reference method for broth dilution antifungal susceptibility testing of conidium-forming filamentous fungi. Proposed standard NCCLS document 
M38-A National Committee for Clinical Laboratory Standards, Wayne; 2002, National Committee for Clinical Laboratory Standards.

doi:10.1186/1753-6561-8-S4-P114

Cite this article as: Crivelenti et al: Marine natural compounds can be

efficient toward aflatoxigenic Aspergillus flavus strain. BMC Proceedings 2014 8(Suppl 4):P114.

Submit your next manuscript to BioMed Central and take full advantage of:

- Convenient online submission

- Thorough peer review

- No space constraints or color figure charges

- Immediate publication on acceptance

- Inclusion in PubMed, CAS, Scopus and Google Scholar

- Research which is freely available for redistribution

Submit your manuscript at www.biomedcentral.com/submit 